\title{
INTEREST RATE LINKAGES IN EMU COUNTRIES: A ROLLING THRESHOLD VECTOR ERROR- CORRECTION APPROACH
}

\author{
TIGRAN POGHOSYAN \\ JAKOB DE HAAN
}

\begin{abstract}
CESIFO WORKING PAPER NO. 2060
CATEgory 6: MONETARy POLICY AND INTERnATIONAL FinanCE JULY 2007
\end{abstract}

An electronic version of the paper may be downloaded

- from the SSRN website:

- from the RePEc website: www.SSRN.com

- from the CESifo website: www.RePEc.org www.CESifo-group.de 


\title{
INTEREST RATE LINKAGES IN EMU COUNTRIES: A ROLLING THRESHOLD VECTOR ERROR- CORRECTION APPROACH
}

\begin{abstract}
This paper revisits financial market integration in the European Economic and Monetary Union, using a threshold vector error-correction model (TVECM) for a fixed rolling window. This approach enables us to analyze the dynamics of transaction costs and detect any comovements with (policy induced) changes in the financial environment. The TVECM methodology is applied on interest rates from different financial markets (government bonds, deposits, loans and mortgages) in Germany, France, Italy, Belgium and the Netherlands for the 1980-2006 period. Our main finding is that only for some country pairs and financial market segments there is evidence in support of financial integration.
\end{abstract}

JEL Code: E43, F36.

Keywords: interest rate linkages, financial integration, EMU, threshold vector errorcorrection.

\author{
Tigran Poghosyan \\ University of Groningen \\ Faculty of Economics \\ PO Box 800 \\ 9700 AV Groningen \\ The Netherlands \\ t.poghosyan@rug.nl
}

\author{
Jakob de Haan \\ University of Groningen \\ Faculty of Economics \\ PO Box 800 \\ 9700 AV Groningen \\ The Netherlands \\ jakob.de.haan@rug.nl
}

June 2007

We acknowledge helpful comments from Jan Jacobs, Anders Rahbek and participants of the Tinbergen Institute conference "20 Years of Cointegration", March 23-24, 2007. The estimations are performed using a modified version of the GAUSS code kindly provided by Stephan Brosig and Enno-Burghard Weitzel from IAMO (Halle, Germany). 


\section{Introduction}

The integration of European financial markets has been on the research agenda since the launch of the European Monetary System (henceforth, EMS) in 1979. ${ }^{1}$ Financial integration has important economic benefits: it leads to greater opportunities for risk sharing and consumption smoothing (Cochrane 1991; Townsend 1994), improved capital allocation and potential for higher economic growth (Levine 1997) and, last but not least, to a more efficient conduct of a common monetary policy and symmetric transmission of monetary policy shocks across countries in the currency union (Suardi 2001).

According to the definition by Baele et al. (2004), financial markets are considered to be integrated if for a given set of financial instruments all potential market participants with the same relevant characteristics: (a) face a single set of rules in dealing with the financial instruments; (b) have equal access to the mentioned set of financial instruments; and (c) are treated equally when they are active in the market. Baele et al. (2004) discuss various approaches for measuring integration of financial markets. One approach is to use quantity-based indicators, which measure cross-border activity and assume that the more frequently cross-border capital flows take place, the more integrated the markets are. The major limitation of this approach is that the absence of cross-border activity can itself be interpreted as a signal that market integration has already been achieved.

Price-based indicators do not suffer from this problem of interpretability. These indicators are based on the Law of One Price (LOOP) according to which financial instruments with similar risk and cash-flow characteristics should be priced similarly in different countries. However, this approach is not flawless too, since it requires the availability of data on financial instruments with similar characteristics. The presence of non-homogenous financial instruments complicates the interpretation of non-convergence as evidence of absence of financial integration.

Intuitively, one could argue that even if interest rates across markets do not converge, the markets may still be integrated if they respond to common factors in a similar

\footnotetext{
${ }^{1}$ The literature on the financial integration process in Europe is extensively discussed in recent papers by Adam et al. (2002), Zhou (2003), Baele et al. (2004), and Sander and Kleimeier (2004).
} 
way. This leads to the concept of news-based indicators, which call for application of cointegration analysis to investigate long-run co-movements in interest rates. However, this approach allows for the possibility of integrated financial markets with interest rates drifting apart in the long-run equilibrium, which is difficult to justify from the market integration point of view.

Our approach is to combine the positive characteristics of price-based and news-based indicators into a more tractable measure. In particular, we acknowledge the possibility of thresholds in the behavior of interest rate co-movements across countries. The rationale for the existence of such thresholds is the presence of transaction costs in arbitrage, differences in legal frameworks and tax codes, asymmetric information issues, exchange rate risks etc. On the one hand, the existence of a cointegrating relationship between interest rates in the absence of convergence can be taken as an argument in favor of market integration. On the other hand, the recent introduction of a common monetary policy and the coordination of fiscal policies are likely to have decreased the magnitude of the thresholds hampering interest rate convergence. The most obvious example is the elimination of exchange rate risks following the introduction of the euro in 1999. Our aim is to provide a quantitative assessment of the extent to which financial markets in some EMU countries have become both integrated and converged over time.

This paper contributes to the existing literature in the following respects:

1. We apply the bivariate threshold vector cointegration methodology, which has several appealing features in comparison to the methodologies used before. First, it is free of the assumption of exogeneity imposed in univariate studies and utilizes the full structure of the model. Second, it allows for the possibility of non-linear adjustment towards long-run equilibrium. ${ }^{2}$ More specifically, it allows to calculate the size of the "neutral band", within which there is no incentive to arbitrage and therefore no convergence to the long-run equilibrium.

\footnotetext{
${ }^{2}$ Earlier attempts to apply threshold methodology for studying financial market integration in EMU countries are limited to univariate models, which do not take feedback effects in country-pair relationships into account (Sander and Kleimeier 2004).
} 
2. We apply the rolling threshold cointegration technique that enables us to estimate the dynamics of estimated thresholds and to assess how financial markets converge over time.

3. We apply data from different segments of financial markets, including money market rates and retail banking rates, which enables us to compare interest rate convergence in different financial markets based on the same methodology.

Our main finding is that only for some country pairs and financial market segments there is evidence in support of financial integration.

The paper is organized as follows. Section 2 provides a discussion on methodological approaches for measuring financial market integration. Section 3 presents the data and estimation results. The final section concludes.

\section{Review of the methodological approaches}

\subsection{Decomposition of interest rate differentials}

The relationship between interest rates in different countries is grounded on the arbitrage possibilities in international financial markets and the Law of One Price (LOOP). One of the representations of the LOOP in international finance is the covered interest parity condition (CIP):

$$
i_{t}-i_{t}^{*}=f_{t}-s_{t}
$$

where $f_{t}$ is a log forward exchange rate at time $t$ for delivery at time $t+1, s_{t}$ is the $\log$ spot exchange rate, and $i_{t}$ and $i_{t}^{*}$ are domestic and foreign interest rates, respectively. The CIP relationship assumes risk neutral behavior, under which the marginal gain of holding domestic currency (forward discount) must be offset by the opportunity costs of holding funds in domestic currency (interest differential). The presence of exchange rate uncertainty together with the more realistic assumption of risk averse behavior $\left(f_{t}=\right.$ $\left.E_{t}\left[s_{t+1}\right]+R P_{t}\right)$ and rational expectations $\left(s_{t+1}=E_{t}\left[s_{t+1}\right]+\varepsilon_{t+1}\right)$ brings us to the uncovered interest parity condition: 


$$
i_{t}-i_{t}^{*}=\left[s_{t+1}-s_{t}\right]-\varepsilon_{t+1}+R P_{t}
$$

where $\varepsilon_{t+1}$ is the rational expectations forecast error at time $t+1, R P_{t}$ is a time-varying foreign exchange risk premium, and $E_{t}($.$) is mathematical expectation operator condi-$ tional on information at time $t$. The above representation of interest differential suggests that its stochastic properties are related to the stochastic properties of its three components. The first component is the exchange rate change, which was widely documented to be a martingale difference process (Meese and Singleton 1982; Meese and Rogoff 1983; and Baillie and Bollerslev 1989). The second component is the rational expectations error component, which by definition is independent on the information at time $t$ and $\mathrm{I}(0)$. The final component is the foreign exchange risk premium, which is the only component which stochastic properties cannot a priori be judged, although there is no asset pricing model that predicts stochastic trending behavior of the currency risk premium.

\subsection{Cointegration analysis}

Interest parity conditions provide a ground for cointegrating relationship between crosscountry interest rates. However, the empirical evidence on the existence of cointegrating relationship is mixed. Karfakis and Moschos (1990), Katsimbris and Miller (1993), and Hassapis et al. (1999), among others, fail to find cointegrating relationship between interest rates in countries participating in the European Exchange Rate System (EMS) and German rates. This finding suggests the presence of non-stationary risk premia in the EMS currencies, which is difficult to justify on theoretical grounds. Later studies resort to structural breaks in the data and misspecification due to omitted deterministic trends to explain the absence of cointegration.

Zhou (2003) argues that rejection of existence of bivariate long-run relationships between interest rates in EMS countries may stem from the misspecification of the model. European countries coordinated their fiscal and monetary policies during several decades, which has introduced trending behavior in the interest rates series. By including a deterministic trend component in the specification of the data generating process of interest 
rates and focusing on three different sub-samples, Zhou (2003) re-establishes the presence of long-run cointegrating relationships, especially for the period of the late 1990s. He concludes that interest rates in the EMS countries move together more closely over time suggesting increased financial integration. Similarly, looking at the relatively long period from 1985 to 2002, Kleimeier and Sander (2000) and Kleimeier and Sander (2006) identify different phases of cointegration in the euro zone retail banking markets. There is evidence of weak cointegration before 1993, which disappears in the mid 1990s to be re-established in the late 1990s following the launch of the single currency. Interestingly, the authors find that cointegration has strengthened even earlier than the introduction of the euro in 1999, reflecting the anticipation of the launch. In addition, they find different results for different segments of the retail market, with the highest degree of cointegration in the market for corporate lending and the lowest degree of cointegration in the markets for saving and demand deposits.

The problem with standard cointegration techniques is that they fail in interpreting the existence of a cointegrating relationship as evidence of market integration, particularly because during the transformation period the relationships are changing over time. According to Brada et al. (2005), if the countries were in the process of convergence over time, the test of the convergence hypothesis would be biased toward rejecting cointegration, and, thus, convergence. Furthermore, since the convergence takes place gradually, conventional tests for a structural break in the data tend to reject the null of the presence of the break. Applying the cointegration methodology for rolling samples can overcome this problem by explicitly taking into account that series may be more cointegrated in certain subsamples than in others.

\subsection{Threshold cointegration analysis}

Another critique of the standard cointegration technique is that it does not take into account the impact of possible market frictions (including cross-country barriers, various restrictions, and asymmetric information) and transaction costs on the adjustment of interest rates towards the long-run equilibrium. In the standard cointegration framework, 
adjustment to the long-run equilibrium is linearly dependent on the magnitude of the deviation. In practice, however, market frictions introduce a non-linear adjustment to the long-run equilibrium (Balke and Fomby 1997). The idea is that market imperfections result in a "neutral band" around the long-run equilibrium path, within which there is no incentive for arbitrage. Therefore, for the adjustment to take place the deviations from the long-run equilibrium should be large enough to cross the transaction costs band and induce arbitrage across markets.

A popular approach designed to account for transaction costs in the adjustment to the long-run equilibrium is the threshold cointegration methodology. This approach was pioneered by Balke and Fomby (1997) and generalized to the multiple equations setting by Hansen and Seo (2002). The appealing feature of the threshold cointegration approach is that it allows to estimate the transaction costs band (which is usually not observable from the data) explicitly and test for its significance.

The invention of the threshold cointegration methodology has spawned a stream of empirical studies on market integration in different fields of economics. ${ }^{3}$ Some of these are in the financial markets literature (see Franses and van Dijk 2000). Siklos and Granger (1997) apply regime-sensitive cointegration methodology to the US and Canadian financial markets and find cointegration only beyond some threshold. Balke and Wohar (1998) study the case of the US and UK financial markets integration. They report that the equilibrium relationship between two interest rate series is more persistent within the transaction costs band, while deviations from disequilibrium tend to be smoothed out faster outside the band. Finally, Peel and Taylor (2002) apply the threshold cointegration methodology for US and UK data in the late 1920s. They find strong evidence in favor of transaction costs band in the covered interest parity relationship. Deviations from the long-run equilibrium become significantly mean reverting outside the neutral band, but within the band they exhibit moderately persistent behavior.

Sander and Kleimeier (2004) apply threshold autoregressive models (TAR) for studying market integration in European retail banking. These authors hypothesize that inter-

\footnotetext{
${ }^{3}$ Lo and Zivot (2001) offer an extensive review of this growing literature.
} 
est rate pass-through across European countries exhibits non-linear adjustment dynamics. To check the validity of their hypothesis, they compare the performance of univariate threshold autoregressive models with their linear counterparts. They find support for the presence of non-linear adjustment in the majority of retail interest rates. However, these authors apply only univariate threshold models and do not extend their analysis to the bivariate setting. As argued by Lo and Zivot (2001), a bivariate extension of the threshold model allows one to uncover potential non-linearities and asymmetries in the adjustment of individual series and provides more information regarding the dynamics of the data. Furthermore, the multivariate procedure for testing threshold cointegration utilizes the full structure of the model and ignores restrictions imposed by the univariate specification. Based on Monte Carlo simulations, Lo and Zivot (2001) show that multivariate models have higher power in detecting threshold effects than their univariate counterparts.

\subsection{Multivariate threshold error correction models}

As mentioned above, Balke and Fomby (1997) proposed application of threshold errorcorrection methods in univariate settings. Lo and Zivot (2001) and Bec and Rahbek (2004) extended their approach to a multivariate threshold cointegration model with a known cointegrating vector. Hansen and Seo (2002) proposed a maximum likelihood procedure for estimating multivariate threshold error-correction model when the cointegrating vector is unknown.

Our empirical investigation builds on a two-regime bivariate threshold cointegration specification proposed by Hansen and Seo (2002):

$$
\begin{aligned}
\Delta Y_{t}= & \left(\mu_{1}+\sum_{j=1}^{k} \Gamma_{1 j} \Delta Y_{t-j}+\Pi_{1} E C T_{t-1}\right) I\left(\left|E C T_{t-1}\right| \leq \gamma\right)+ \\
& \left(\mu_{2}+\sum_{j=1}^{k} \Gamma_{2 j} \Delta Y_{t-j}+\Pi_{2} E C T_{t-1}\right) I\left(\left|E C T_{t-1}\right|>\gamma\right)+\epsilon_{t}
\end{aligned}
$$

where $Y_{t}=\left(r^{i}, r^{j}\right)^{\prime}$ is a vector of nominal interest rates for countries $i$ and $j$, respectively, $I($.$) is an indicator function depending on the size of the deviation from the long-run$ 
equilibrium in the previous period $\left(E C T_{t-1}\right)$ relative to the threshold parameter $(\gamma), \mu_{1}$ and $\mu_{2}$ are $2 \times 1$ vectors of intercepts, $\Gamma_{1 j}$ and $\Gamma_{2 j}$ are $2 \times 2$ matrices of constant parameters representing short-run responses, and $\Pi_{1}$ and $\Pi_{2}$ are $2 \times 2$ diagonal matrices representing speed of adjustment to the long-run equilibrium in the first and second regimes, respectively, $k$ is the number of lags and $\epsilon_{t}$ are i.i.d. Gaussian disturbances. This specification assumes that when deviations from the long-run equilibrium are not sufficiently large with respect to the threshold parameter (regime 1), then the price transmission process is defined somewhat differently from the alternative case (regime 2). In particular, the speed of adjustment parameters $\Pi$ are assumed to have lower values in the non-adjustment regime (regime 1) and potentially could be even insignificant (see Figure 1).

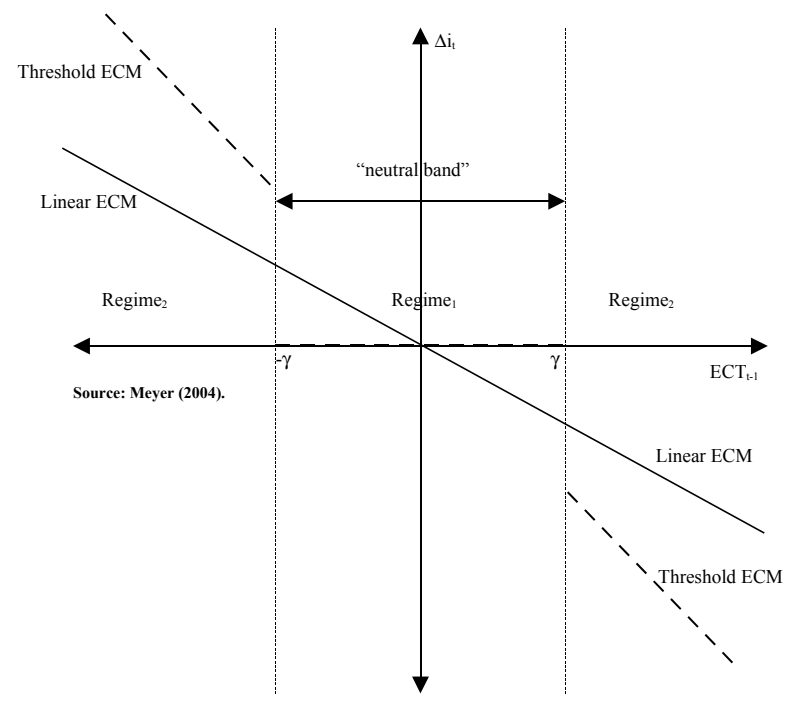

Figure 1: Visual representation of TVECM model

The algorithm for the threshold vector error-correction model (TVECM) estimation procedure contains three steps. The first step consists of testing for stationarity and cointegration using ADF and Johansen (1991) tests, respectively. In the second step, the series that are integrated of order one are used in a standard linear error-correction model. In the final step, the TVECM is estimated for the cointegrated series. For this purpose, 
the threshold parameter $\gamma$ is determined using the following selection criteria: ${ }^{4}$

$$
\xi(\hat{\gamma})=\min \left(\log \left|\frac{1}{n} \sum_{t=1}^{n} \hat{\varepsilon}_{t}(\gamma) \hat{\varepsilon}_{t}(\gamma)^{\prime}\right|\right)
$$

Once the value of $\gamma$ that minimizes (4) is chosen, an additional restriction that each regime should contain at least a pre-specified fraction of the total sample $\left(\pi_{0}\right)$ is imposed on this grid search procedure: ${ }^{5}$

$$
\pi_{0} \leq P\left(\left|E C T_{t-1}\right| \leq \gamma\right) \leq 1-\pi_{0}
$$

The statistical significance of the threshold parameter $\gamma$ (the nuisance parameter) contains elements of non-standard inference. Therefore, the p-values are calculated using SupLM test and the bootstrapping techniques proposed by Hansen and Seo (2002).

Using the TVECM approach for rolling sub-samples enables us to observe the evolution of transaction costs bands over different time intervals. Our argument is that the more integrated the markets are, the smaller the transaction costs band should be, taking other parameters constant. Therefore, diminishing dynamics of transaction costs band over time is considered as evidence in favor of the gradual integration of financial markets in EMU member states.

\section{Data and Estimation Results}

Interest rate series we are employing in our estimations cover different segments of financial markets in the five largest EMU economies: Germany, France, Italy, Belgium and the Netherlands. The dataset includes series on yields on government bonds, deposits, loans and mortgage contracts (see Table 1). The total sample includes periods before and after the introduction of the single currency. The subsamples used for rolling estimations are fixed to 15 years period (180 months). The data is obtained from the IMF's International Financial Statistics and the ECB's Statistical Data Warehouse databases. The series on

\footnotetext{
${ }^{4}$ Here we follow Meyer (2004) and assume that the cointegration vector is known, so that the search is performed only with respect to the threshold parameter $\gamma$. In the Hansen and Seo (2002) methodology the search is performed also with respect to the cointegration vector.

${ }^{5}$ In our estimations we use $\pi_{0}=10 \%$.
} 
retail rates (deposits, loans and mortgages) are harmonized MFI series for the period after 2003. Since these series are not available for the period before 2003, we extrapolated the data for earlier periods by using monthly changes of national retail interest rate series (NRIR) available from the ECB database, using the following formula:

$$
i_{m, t}=i_{m, t+1} \frac{i_{N R I R, t}}{i_{N R I R, t+1}}
$$

where $i_{m, t}$ is the retail (deposit, loan and mortgage) rate in period $t$ and $i_{N R I R, t}$ is the corresponding rate supplied by the National Banks for the period before 2003 .

Figure 2 displays the dynamics of the series. Preliminary examination of the plot suggests different convergence patterns, both over time and across financial markets. The elimination of exchange rate risks following the launch of the euro in 1999 has stimulated convergence in bond rates and deposit rates, but the loan and mortgage market yields have been less affected.

We start our analysis by running Augmented Dickey-Fuller (ADF) tests on the series to test for stationarity. ${ }^{6}$ Practically all the series were found to be stationary of the first order (see Table 2). Given that the series are not stationary in levels, we proceed by checking whether they are cointegrated.

As argued by Zhou (2003), empirical tests of cointegration in European financial markets based on the total sample are biased toward rejection of cointegration if a deterministic trend is omitted from the specification of the data generating process of the independent variables. In our error correction specification we therefore allow for a deterministic trend in the data generating process of interest rate series. As economic policies were aimed at integration during our sample period, similar to Brada et al. (2005) we apply rolling cointegration to measure dynamics of convergence in interest rates over time.

Following the conventional stream of the literature, we apply Johansen (1991) cointegration rank test, which is based on the following vector autoregressive (VAR) system:

\footnotetext{
${ }^{6}$ We use the ADF specification which allows for an intercept and linear trend to be present in the data generating process.
} 


$$
\Delta X_{t}=\sum_{j=1}^{k-1} \Gamma_{j} \Delta X_{t-j}+\Pi X_{t-1}+c_{0}+\varepsilon_{t}
$$

where $X_{t}$ is a vector of $n$ variables, $c_{0}$ is a constant term and $\varepsilon_{t}$ is a vector of Gaussian errors with mean zero and variance-covariance matrix $\Sigma$. Inclusion of $c_{0}$ allows a linear time trend to be present in the data generating process of $X_{t}$. The cointegration hypotheses involve properties of the matrix $\Pi$. If the rank of $\Pi$ is $r$, where $r \leq n-1$, then $r$ is called the cointegration rank and $\Pi$ can be decomposed into two $n \times r$ matrices, $\alpha$ and $\beta$, such that $\Pi=\alpha \beta^{\prime}$. The economic interpretation of the components of matrix $\Pi$ is as follows: $\beta$ consists of $r$ linear cointegrating vectors, while $\alpha$ represents $r$ vector error correction parameters. Cointegration tests are carried out using Johansen (1991)'s maximum eigenvalue $\left(\lambda_{\max }\right)$ tests with critical values provided in Osterwald-Lenum (1992). Since our estimations are applied to a set of country pairs, our null hypothesis is $r=0$ cointegrating relationships (no cointegration) against $r=1$ relationships (cointegration).

Several conclusions can be drawn from Table 3. First, the hypothesis of no cointegration cannot be rejected for the majority of country pairs for the total sample period estimates. This finding does not come as a surprise since the total sample includes several periods corresponding with different degrees of monetary integration (see Zhou 2003). Second, for most of the country pairs there are quite a few subsamples where cointegration is present. In some of these cases the frequency of subsample cointegration relationships is high. For example, for the bonds market there are three country pairs (GE-FR, BE-FR and FR-NL) for which the number of subsamples with cointegrating relationships clearly exceeds the number of subsamples without cointegration. ${ }^{7}$ This suggests that frequent structural changes occurred in the total sample.

Figure 3 provides further insight on the dynamics of the cointegration relationship. Several conclusions follow from this table. First, in many country-pair cases there exists a cointegrating relationship somewhere at the beginning of the sample, and/or closer to the end of the sample. For instance, bond rates in Italy were not cointegrated with the

\footnotetext{
${ }^{7}$ All the three country pairs include French rates. Similarly, for the case of loans and mortgage markets, this situation applies to the country pairs which include German rates.
} 
rest of EMU countries in the early days of the ERM; cointegration was established in the early 1990s and disappeared afterwards. This type of "yes-no-yes" pattern was also documented by Sander and Kleimeier (2004). Second, in some cases we find persistent cointegration (this applies to mortgage rates in Germany and the Netherlands, deposits in Belgium and France, France and the Netherlands, loans in Germany and the Netherlands, and Belgium and the Netherlands). A comparison with Table 3 shows that in some cases where cointegration is constantly found in subsamples, it is rejected for the total sample (e.g. deposits in Belgium and France), suggesting that structural changes took place.

For the subsamples with cointegration, we investigate whether the convergence to the long-run equilibrium exhibits a non-linear pattern. For this purpose, we estimate the TVECM (3) and test for significance of the threshold parameter $\gamma$ (using a $10 \%$ confidence interval) for the rolling subsamples for which the cointegration hypothesis was not rejected. Unfortunately, for the threshold models usual asymptotic theory can not be applied to test for autocorrelation in residuals (see Lukkonen et al., 1988). In the absence of a methodology for specification testing, we set the number of lags in our estimations to 2 for each of the subsamples.

The estimation results of the rolling threshold vector error-correction models are displayed in Figure 4. For the bond markets, we find evidence of significant thresholds only in four out of ten country pairs. Out of those four country pairs, only for the case of Belgium and France there is a clear evidence of decreasing thresholds, while the other country pairs do not reveal decreasing threshold behavior. In addition, it is worth noting that for Italy cointegration is rejected for the early periods (before 1990). After the beginning of the 1990s, significant thresholds do not exhibit a decreasing pattern, implying slow convergence. In contrast, the estimated thresholds for pairs GE-FR and FR-NL exhibit a clear decreasing pattern, but they are not significant.

For the mortgage market, there is a systematic threshold adjustment present in the case of Germany and the Netherlands. The thresholds slightly decline, suggesting market integration. It is widely documented that mortgage markets are segmented in European countries. However, as mentioned in Kleimeier and Sander (2006), in this case the para- 
doxical situation appears that the mortgage rates are moving closely together and previous techniques were unable to capture the reality of market segmentation. The threshold cointegration method is more informative in this respect.

Finally, the deposit and loan markets shows completely opposite patterns. First, these markets exhibit contrasting rolling cointegration results: no cointegration in loan markets for subsamples during which deposit markets are cointegrated, and vice versa. Second, the significant thresholds are mostly detected in non-overlapping subsamples across the two markets. The most persistent threshold behavior is detected for loans markets in Belgium and the Netherlands. The threshold does not exhibit a decreasing pattern. There is some evidence of decreasing thresholds for loan markets in Germany and the Netherlands, as well as deposit market in Belgium and the Netherlands, but the number of subsamples where the threshold is detected is not large. It is also important to notice that the threshold parameters are larger in magnitude for the loan and deposit markets relative to the bond and mortgage markets, which suggests higher transaction costs in these European financial markets.

\section{Conclusion}

In this paper we revisit the issue of interest rate linkages and financial market integration in selected European countries using rolling threshold vector error-correction models. We propose a methodological improvement in measuring interest rate linkages and financial integration, combining price- and news-based indicators into one measure. In addition, our approach allows for time varying transaction costs in arbitrage across spatially separated markets.

Our conclusion is that there is evidence of decreasing thresholds over time for certain markets and certain country pairs. Over time, the number of cases where the hypothesis of cointegration cannot be rejected increases, which indicates strengthening of the crosscountry interest rate linkages over time. Estimated threshold parameters are found to be larger for deposit and loan markets relative to the bond and mortgage markets, indicating higher transaction costs. 
There are several reasons why our findings should be interpreted with caution. First, in our analysis we use a rolling window of 15 years, so there might still be structural changes present in these subsamples. However, decreasing the size of the subsamples would diminish the power of the threshold models. Second, in most of the cases we do not find significant thresholds towards the end of the total sample, when the euro was introduced. We interpret this finding as evidence of stronger intercountry interest linkages. 


\section{References}

Adam, K., T. Japelli, A. Menichini, M. Padula, and M. Pagano. 2002. Analyze, Compare, and Apply Alternative Indicators and Monitoring Methodologies to Measure the Evolution of Capital Market Integration in the European Union. Report to the European Commission.

Baele, L., A. Fernando, P. Hordahl, E. Krylova, and C. Monnet. 2004. Measuring Financial Integration in the Euro Area. ECB Occasional Paper Series, No. 14, Frankfurt.

Baillie, R., and T. Bollerslev. 1989. "Common Stochastic Trends in a System of Exchange Rates." Journal of Finance 44:167-181.

Balke, N., and T. Fomby. 1997. "Threshold Cointegration." International Economic Review 38:627-645.

Balke, N., and M. Wohar. 1998. "Nonlinear Dynamics and Covered Interest Parity." Empirical Economics 23:535-559.

Bec, F., and A. Rahbek. 2004. "Vector Equilibrium Correction Models with Non-linear Discontinuous Adjustment." Econometrics Journal 7:628-651.

Brada, J., A. Kutan, and S. Zhou. 2005. "Real and Monetary Convergence between the European Union's Core and Recent Member Countries: A Rolling Cointegration Approach." Journal of Banking and Finance 29:249-270.

Cochrane, J. 1991. "A Simple Test of Consumption Insurance." Journal of Political Economy 99:957-976.

Franses, P., and D. van Dijk. 2000. Non-Linear Time Series Models in Empirical Finance. Cambridge University Press, UK.

Hansen, B., and B. Seo. 2002. "Testing for Two-regime Threshold Cointegration in Vector Error-correction Models." Journal of Econometrics 110:293-318.

Hassapis, C., N. Pittis, and K. Prodromidis. 1999. "Unit Roots and Granger Causality in the EMS Interest Rates: The German Dominance Hypothesis Revisited." Journal of International Money and Finance 18:47-73.

Johansen, S. 1991. "Estimation and Hypothesis Testing of Cointegration Vectors in Gaussian Vector Autoregressive Models." Econometrica 59:1551-1580.

Karfakis, C., and D. Moschos. 1990. "Interest Rate Linkages within the European Monetary System: A Time Series Analysis." Journal of Money, Credit and Banking 22:388-394.

Katsimbris, G., and S. Miller. 1993. "Interest Rate Linkages within the European Monetary System: Further Analysis." Journal of Money, Credit and Banking 25:771779 .

Kleimeier, S., and H. Sander. 2000. "Regionalisation versus Globalisation in European Financial Market Integration: Evidence from Co-Integration Analysis." Journal of Banking and Finance 24:1005-1043. 
. 2006. "Regional Versus Global Integration of Eurozone Retail Banking Markets: Understanding the Recent Evidence from Price-Based Integration Measures." Quarterly Review of Economics and Finance 46:353-368.

Levine, R. 1997. "Financial Development and Economic Growth: Views and Agenda." Journal of Economic Literature 35:688-726.

Lo, M., and E. Zivot. 2001. "Threshold Cointegration and Nonlinear Adjustment to the Law of One Price." Macroeconomic Dynamics 5:533-576.

Lukkonen, R., P. Saikkonen, and T. Teräsvirta. 1988. "Testing Linearity Against Smooth Transition Autoregressive Models." Biometrika 75:491-499.

Meese, R., and K. Rogoff. 1983. "Empirical Exchange Rate Models of the Seventies: Do They Fit Out of Sample?" Journal of International Economics 14:3-24.

Meese, R., and K. Singleton. 1982. "On Unit Roots and the Empirical Modeling of Exchange Rates." Journal of Finance 37:1029-1035.

Meyer, J. 2004. "Measuring Market Integration in the Presence of Transaction Costs A Threshold Vector Error Correction Approach." Journal of Agricultural Economics 31:327-334.

Osterwald-Lenum, M. 1992. "A Note with Quantiles of the Asymptotic Distribution of the Maximum Likelihood Cointegration Rank Test Statistics." Oxford Bulletin of Economics and Statistics 54:461-472.

Peel, D., and M. Taylor. 2002. "Covered Interest Arbitrage in the Inter-war Period and the Keynes-Einzig Conjecture." Journal of Money, Credit and Banking 34:51-75.

Sander, H., and S. Kleimeier. 2004. "Convergence in Eurozone Retail Banking? What Interest Rate Pass-Through Tells Us About Monetary Policy Transmission, Competition and Integration." Journal of International Money and Finance 23:461-492.

Siklos, P., and C. Granger. 1997. "Regime-Sensitive Cointegration with an Application to Interest-Rate Parity." Macroeconomic Dynamics 1:640-657.

Suardi, M. 2001. EMU and Asymmetries in the Monetary Policy Transmission. Economic paper 157, European Commission, Brussels.

Townsend, R. 1994. "Risk and Insurance in Village India." Econometrica 62:539-591.

Zhou, S. 2003. "Interest Rate Linkages within the European Monetary System: New Evidence Incorporating Long-Run Trends." Journal of International Money and Finance $22: 571-590$. 
Table 1: Data description

\begin{tabular}{llll}
\hline Financial instruments & Countries & Time span & \# of obs. \\
Government bonds & BE, GE, FR, IT, NL & Jan1987-July2006 & 235 \\
Loans to enterprizes & BE, GE, FR, NL & Apr1984-Sep2006 & 270 \\
Time deposits & BE, GE, FR, NL & Jan1980-Sep2006 & 321 \\
Mortgage contracts & BE, GE, NL & Jun1982-Sep2006 & 292 \\
\hline
\end{tabular}

Source: Statistical Data Warehouse (ECB) and International Financial Statistics (IMF).

Table 2: Augmented Dickey-Fuller test for stationarity

\begin{tabular}{|c|c|c|c|c|c|c|}
\hline & & $\mathrm{BE}$ & FR & GE & IT & NL \\
\hline \multirow[t]{4}{*}{ bonds } & levels & -2.7966 & -3.0089 & -2.7375 & -2.4112 & -2.7468 \\
\hline & p-value & 0.2001 & 0.1320 & 0.2226 & 0.3728 & 0.2189 \\
\hline & first differences & -13.1816 & -11.5988 & -11.1298 & -11.5308 & -11.3258 \\
\hline & p-value & 0.0000 & 0.0000 & 0.0000 & 0.0000 & 0.0000 \\
\hline \multirow{4}{*}{ deposits } & levels & -2.4035 & -2.4953 & -2.4680 & - & -2.5883 \\
\hline & p-value & 0.3770 & 0.3303 & 0.3439 & - & 0.2860 \\
\hline & first differences & -6.0606 & -13.6531 & -13.5658 & - & -8.1708 \\
\hline & p-value & 0.0000 & 0.0000 & 0.0000 & - & 0.0000 \\
\hline \multirow[t]{4}{*}{ loans } & levels & -2.1976 & -1.8154 & -2.0561 & - & -1.4720 \\
\hline & p-value & 0.4885 & 0.6948 & 0.5674 & - & 0.8369 \\
\hline & first differences & -13.4861 & -7.5187 & -3.9962 & - & -14.6312 \\
\hline & p-value & 0.0000 & 0.0000 & 0.0016 & - & 0.0000 \\
\hline \multirow[t]{4}{*}{ mortgage } & levels & -2.8164 & - & -2.1694 & - & -2.3864 \\
\hline & p-value & 0.1926 & - & 0.5044 & - & 0.3859 \\
\hline & first differences & -6.6531 & - & -11.0558 & - & -10.1089 \\
\hline & p-value & 0.0000 & - & 0.0000 & - & 0.0000 \\
\hline
\end{tabular}

Note: The estimations are performed using ADF test specification, which includes an intercept and trend. Lag selection is based on SchwartzBayes information criterion.

Table 3: Johansen cointegration test results*

\begin{tabular}{|c|c|c|c|c|c|c|c|c|c|c|c|}
\hline & & GE-BE & GE-FR & GE-IT & GE-NL & BE-FR & BE-IT & BE-NL & FR-IT & FR-NL & IT-NL \\
\hline \multirow[t]{3}{*}{ bonds } & \# CI & 25 & 46 & 15 & 0 & 48 & 14 & 13 & 11 & 43 & 3 \\
\hline & \# Not CI & 30 & 9 & 40 & 55 & 7 & 41 & 42 & 44 & 12 & 52 \\
\hline & Total sample & YES & $\mathrm{NO}$ & $\mathrm{NO}$ & $\mathrm{NO}$ & $\mathrm{NO}$ & $\mathrm{NO}$ & $\mathrm{NO}$ & $\mathrm{NO}$ & $\mathrm{NO}$ & $\mathrm{NO}$ \\
\hline \multirow[t]{3}{*}{ deposits } & \# CI & 26 & 35 & - & 16 & 141 & - & 49 & - & 121 & - \\
\hline & \# Not CI & 115 & 106 & - & 125 & 0 & - & 92 & - & 20 & - \\
\hline & Total sample & $\mathrm{NO}$ & YES & - & $\mathrm{NO}$ & $\mathrm{NO}$ & - & $\mathrm{NO}$ & - & YES & - \\
\hline \multirow[t]{3}{*}{ loans } & \# CI & 61 & 8 & - & 86 & 3 & - & 74 & - & 5 & - \\
\hline & \# Not CI & 29 & 82 & - & 4 & 87 & - & 16 & - & 85 & - \\
\hline & Total sample & $\mathrm{NO}$ & $\mathrm{NO}$ & - & $\mathrm{NO}$ & $\mathrm{NO}$ & - & YES & - & $\mathrm{NO}$ & - \\
\hline \multirow[t]{3}{*}{ mortgage } & \# CI & 12 & - & - & 100 & - & - & 17 & - & - & - \\
\hline & \# Not CI & 100 & - & - & 12 & - & - & 95 & - & - & - \\
\hline & Total sample & $\mathrm{NO}$ & - & - & YES & - & - & $\mathrm{NO}$ & - & - & - \\
\hline
\end{tabular}



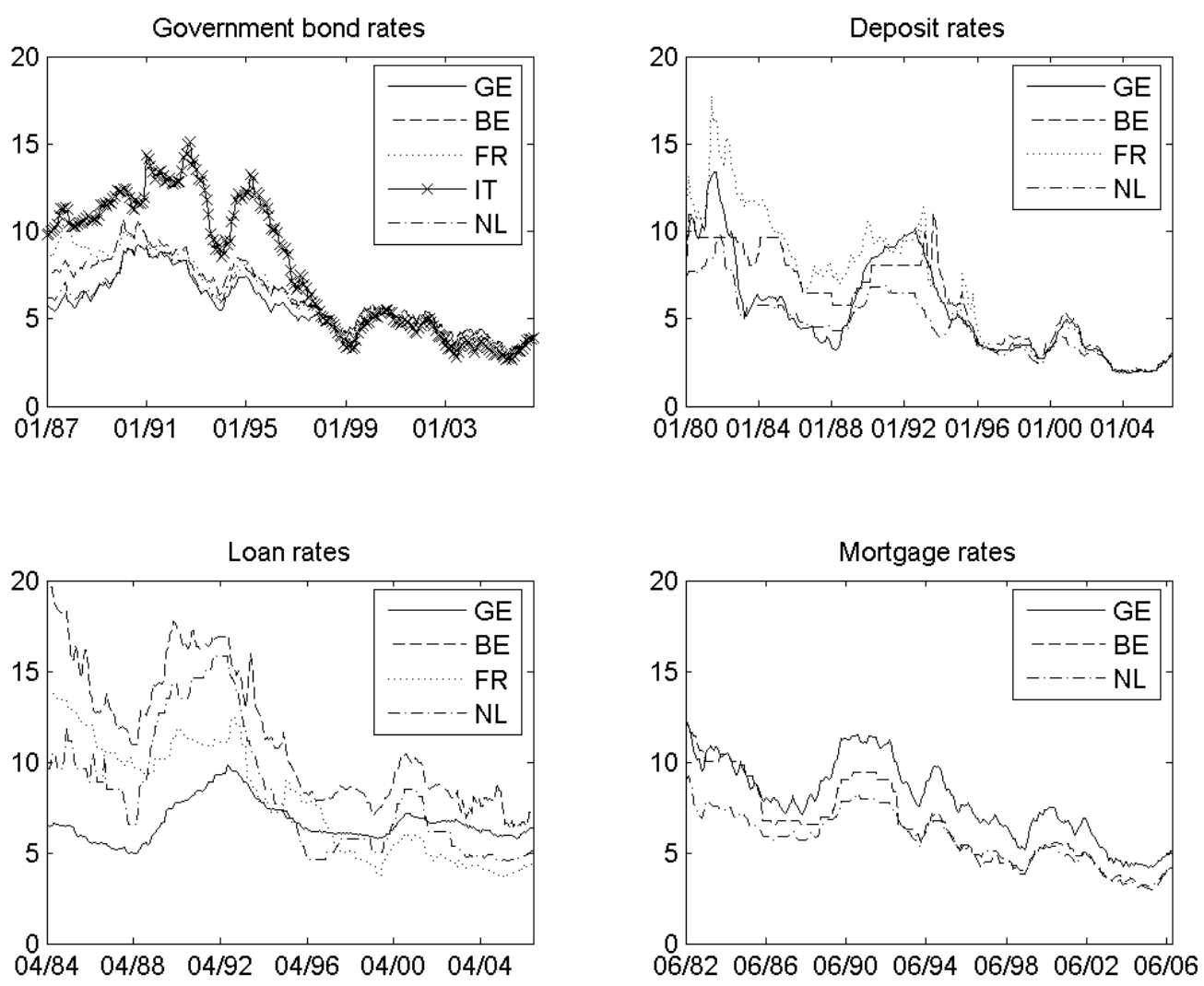

Figure 2: Interest rate series 

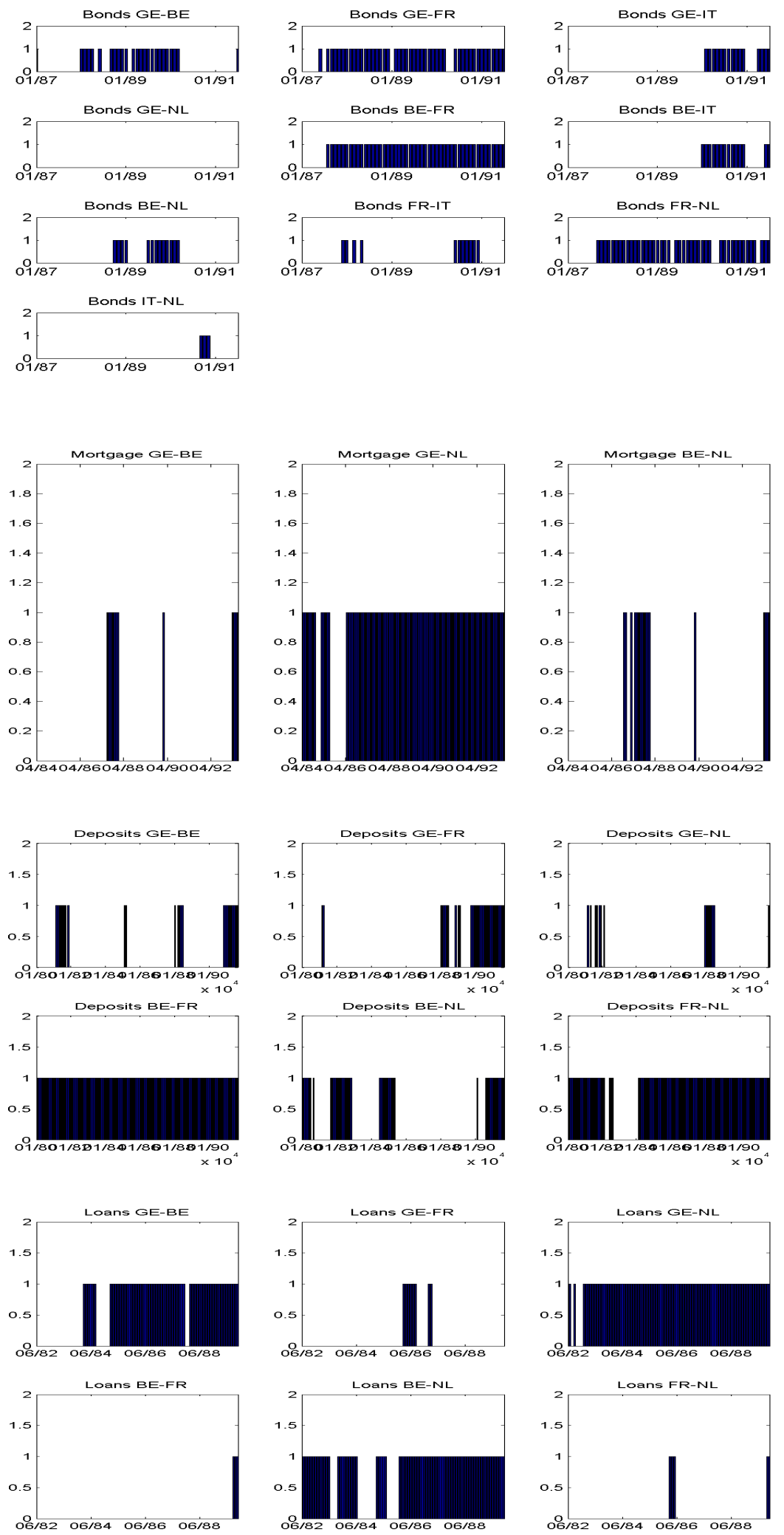

Note: Bars indicate the beginning of the subsample for which the hypothesis of no cointegration is rejected. The absence of a bar implies that we did not find cointegration in a subsample (see also Table 3 ).

Figure 3: Rolling cointegration tests for bond, mortgage, deposit and loan markets. 

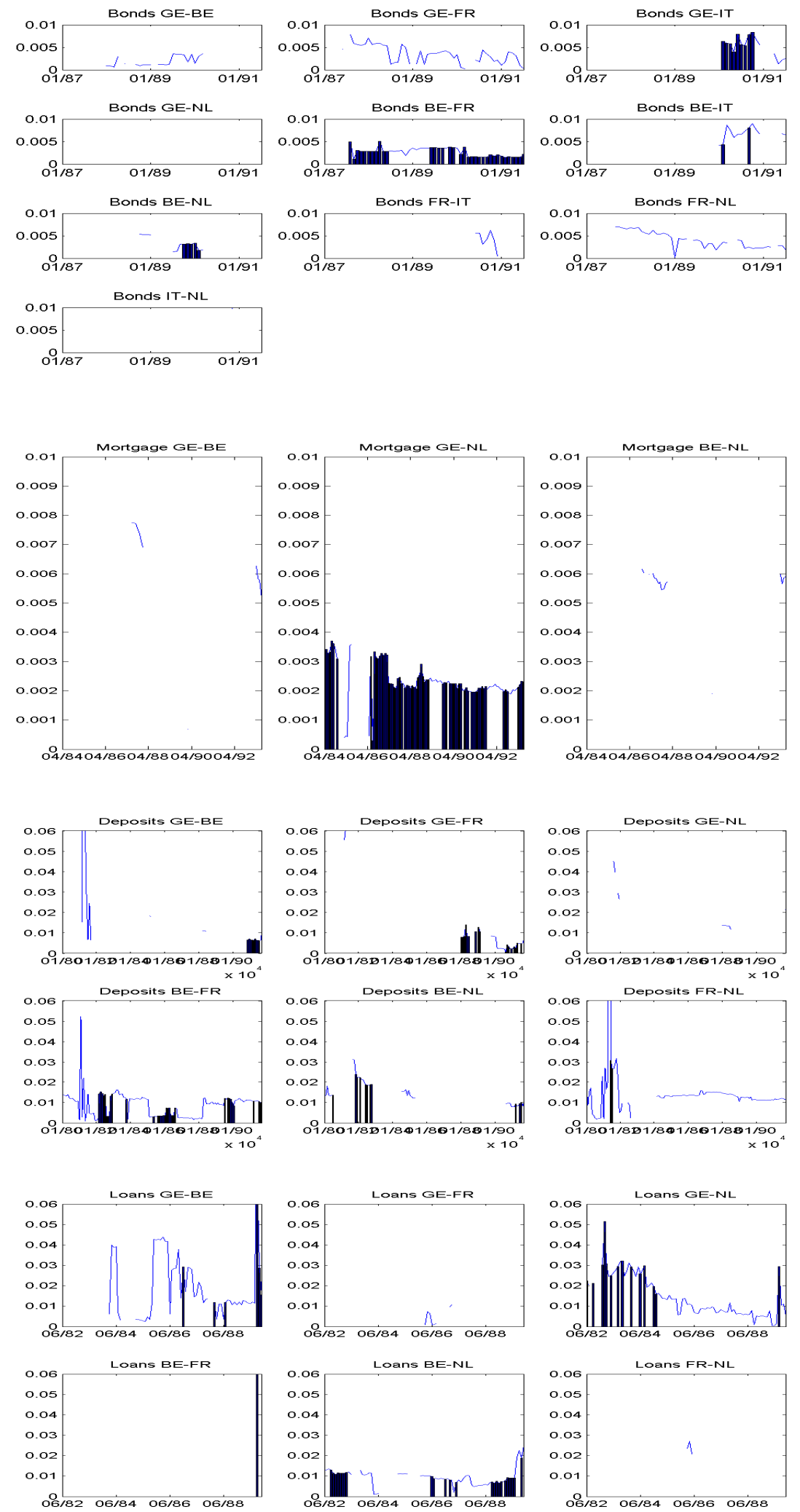

Note: TVECM estimations are performed only for those subsamples where cointegration is found. Solid lines indicate estimated threshold parameter for a given rolling subsample and bars indicate that threshold parameters are significant.

Figure 4: Estimated threshold parameters for bond, mortgage, deposit and loan markets. 


\title{
CESifo Working Paper Series
}

\author{
(for full list see www.cesifo-group.de)
}

1996 J. Atsu Amegashie, Bazoumana Ouattara and Eric Strobl, Moral Hazard and the Composition of Transfers: Theory with an Application to Foreign Aid, May 2007

1997 Wolfgang Buchholz and Wolfgang Peters, Equal Sacrifice and Fair Burden Sharing in a Public Goods Economy, May 2007

1998 Robert S. Chirinko and Debdulal Mallick, The Fisher/Cobb-Douglas Paradox, Factor Shares, and Cointegration, May 2007

1999 Petra M. Geraats, Political Pressures and Monetary Mystique, May 2007

2000 Hartmut Egger and Udo Kreickemeier, Firm Heterogeneity and the Labour Market Effects of Trade Liberalisation, May 2007

2001 Andreas Freytag and Friedrich Schneider, Monetary Commitment, Institutional Constraints and Inflation: Empirical Evidence for OECD Countries since the 1970s, May 2007

2002 Niclas Berggren, Henrik Jordahl and Panu Poutvaara, The Looks of a Winner: Beauty, Gender, and Electoral Success, May 2007

2003 Tomer Blumkin, Yoram Margalioth and Efraim Sadka, Incorporating Affirmative Action into the Welfare State, May 2007

2004 Harrie A. A. Verbon, Migrating Football Players, Transfer Fees and Migration Controls, May 2007

2005 Helmuth Cremer, Jean-Marie Lozachmeur and Pierre Pestieau, Income Taxation of Couples and the Tax Unit Choice, May 2007

2006 Michele Moretto and Paolo M. Panteghini, Preemption, Start-Up Decisions and the Firms’ Capital Structure, May 2007

2007 Andreas Schäfer and Thomas M. Steger, Macroeconomic Consequences of Distributional Conflicts, May 2007

2008 Mikael Priks, Judiciaries in Corrupt Societies, June 2007

2009 Steinar Holden and Fredrik Wulfsberg, Downward Nominal Wage Rigidity in the OECD, June 2007

2010 Emmanuel Dhyne, Catherine Fuss, Hashem Pesaran and Patrick Sevestre, Lumpy Price Adjustments: A Microeconometric Analysis, June 2007 
2011 Paul Belleflamme and Eric Toulemonde, Negative Intra-Group Externalities in TwoSided Markets, June 2007

2012 Carlos Alós-Ferrer, Georg Kirchsteiger and Markus Walzl, On the Evolution of Market Institutions: The Platform Design Paradox, June 2007

2013 Axel Dreher and Martin Gassebner, Greasing the Wheels of Entrepreneurship? The Impact of Regulations and Corruption on Firm Entry, June 2007

2014 Dominique Demougin and Claude Fluet, Rules of Proof, Courts, and Incentives, June 2007

2015 Stefan Lachenmaier and Horst Rottmann, Effects of Innovation on Employment: A Dynamic Panel Analysis, June 2007

2016 Torsten Persson and Guido Tabellini, The Growth Effect of Democracy: Is it Heterogenous and how can it be Estimated?, June 2007

2017 Lorenz Blume, Jens Müller, Stefan Voigt and Carsten Wolf, The Economic Effects of Constitutions: Replicating - and Extending - Persson and Tabellini, June 2007

2018 Hartmut Egger and Gabriel Felbermayr, Endogenous Skill Formation and the Source Country Effects of International Labor Market Integration, June 2007

2019 Bruno Frey, Overprotected Politicians, June 2007

2020 Jan Thomas Martini, Rainer Niemann and Dirk Simons, Transfer Pricing or Formula Apportionment? Tax-Induced Distortions of Multinationals' Investment and Production Decisions, June 2007

2021 Andreas Bühn, Alexander Karmann and Friedrich Schneider, Size and Development of the Shadow Economy and of Do-it-yourself Activities in Germany, June 2007

2022 Michael Rauscher and Edward B. Barbier, Biodiversity and Geography, June 2007

2023 Gunther Schnabl, Exchange Rate Volatility and Growth in Emerging Europe and East Asia, June 2007

2024 Erkki Koskela and Ronnie Schöb, Tax Progression under Collective Wage Bargaining and Individual Effort Determination, June 2007

2025 Jay Pil Choi and Marcel Thum, The Economics of Politically Connected Firms, June 2007

2026 Jukka Pirttilä and Roope Uusitalo, Leaky Bucket in the Real World: Estimating Inequality Aversion Using Survey Data, June 2007

2027 Ruslan Lukach, Peter M. Kort and Joseph Plasmans, Strategic R\&D with Knowledge Spillovers and Endogenous Time to Complete, June 2007 
2028 Jarko Fidrmuc, Neil Foster and Johann Scharler, Labour Market Rigidities, Financial Integration and International Risk Sharing in the OECD, June 2007

2029 Bernardina Algieri and Thierry Bracke, Patterns of Current Account Adjustment Insights from Past Experience, June 2007

2030 Robert Dur and Hein Roelfsema, Social Exchange and Common Agency in Organizations, June 2007

2031 Alexander Libman and Lars P. Feld, Strategic Tax Collection and Fiscal Decentralisation: The Case of Russia, June 2007

2032 Øystein Foros, Hans Jarle Kind and Greg Shaffer, Resale Price Maintenance and Restrictions on Dominant Firm and Industry-Wide Adoption, June 2007

2033 Jan K. Brueckner and Kurt Van Dender, Atomistic Congestion Tolls at Concentrated Airports? Seeking a Unified View in the Internalization Debate, June 2007

2034 Viet Do and Ngo Van Long, International Outsourcing under Monopolistic Competition: Winners and Losers, June 2007

2035 Nadia Fiorino and Roberto Ricciuti, Determinants of Direct Democracy, June 2007

2036 Burkhard Heer and Alfred Maussner, Inflation and Output Dynamics in a Model with Labor Market Search and Capital Accumulation, June 2007

2037 Konstantinos Angelopoulos, Jim Malley and Apostolis Philippopoulos, Public Education Expenditure, Growth and Welfare, June 2007

2038 Maarten Bosker, Steven Brakman, Harry Garretsen and Marc Schramm, Adding Geography to the New Economic Geography, June 2007

2039 Steffen Henzel, Oliver Hülsewig, Eric Mayer and Timo Wollmershäuser, The Price Puzzle Revisited: Can the Cost Channel Explain a Rise in Inflation after a Monetary Policy Shock?, July 2007

2040 Rosario Crinò, Service Offshoring and White-Collar Employment, July 2007

2041 Carsten Hefeker and Michael Neugart, Labor Market Regulation and the Legal System, July 2007

2042 Bart Cockx and Muriel Dejemeppe, Is the Notification of Monitoring a Threat to the Unemployed? A Regression Discontinuity Approach, July 2007

2043 Alfons J. Weichenrieder, Profit Shifting in the EU: Evidence from Germany, July 2007

2044 Annika Alexius and Bertil Holmlund, Monetary Policy and Swedish Unemployment Fluctuations, July 2007 
2045 Axel Dreher, Jan-Egbert Sturm and Jakob de Haan, Does High Inflation Cause Central Bankers to Lose their Job? Evidence Based on a New Data Set, July 2007

2046 Guglielmo Maria Caporale and Luis A. Gil-Alana, Long Run and Cyclical Dynamics in the US Stock Market, July 2007

2047 Alessandro Balestrino, It is a Theft but not a Crime, July 2007

2048 Daniel Becker and Michael Rauscher, Fiscal Competition in Space and Time: An Endogenous-Growth Approach, July 2007

2049 Yannis M. Ioannides, Henry G. Overman, Esteban Rossi-Hansberg and Kurt Schmidheiny, The Effect of Information and Communication Technologies on Urban Structure, July 2007

2050 Hans-Werner Sinn, Please bring me the New York Times - On the European Roots of Richard Abel Musgrave, July 2007

2051 Gunther Schnabl and Christian Danne, A Role Model for China? Exchange Rate Flexibility and Monetary Policy in Japan, July 2007

2052 Joseph Plasmans, Jorge Fornero and Tomasz Michalak, A Microfounded Sectoral Model for Open Economies, July 2007

2053 Vesa Kanniainen and Panu Poutvaara, Imperfect Transmission of Tacit Knowledge and other Barriers to Entrepreneurship, July 2007

2054 Marko Koethenbuerger, Federal Tax-Transfer Policy and Intergovernmental PreCommitment, July 2007

2055 Hendrik Jürges and Kerstin Schneider, What Can Go Wrong Will Go Wrong: Birthday Effects and Early Tracking in the German School System, July 2007

2056 Bahram Pesaran and M. Hashem Pesaran, Modelling Volatilities and Conditional Correlations in Futures Markets with a Multivariate t Distribution, July 2007

2057 Walter H. Fisher and Christian Keuschnigg, Pension Reform and Labor Market Incentives, July 2007

2058 Martin Altemeyer-Bartscher, Dirk T. G. Rübbelke and Eytan Sheshinski, Policies to Internalize Reciprocal International Spillovers, July 2007

2059 Kurt R. Brekke, Astrid L. Grasdal and Tor Helge Holmås, Regulation and Pricing of Pharmaceuticals: Reference Pricing or Price Cap Regulation?, July 2007

2060 Tigran Poghosyan and Jakob de Haan, Interest Rate Linkages in EMU Countries: A Rolling Threshold Vector Error-Correction Approach, July 2007 